\title{
3 \\ The promise of the university: what it's become and where it could go
}

\author{
Crain Soudien
}

\section{Introduction}

he university is an evolving idea. Around the world there are dozens of manifestations of what it could be: large, small, tied to corporates such as Microsoft, underwritten by foundations such as the Aga Khan Foundation, focused on single professions such as medicine, business or engineering - all of these present themselves as universities. In these forms the university has moved a long way from the classic medieval institution that one saw in Bologna, Oxford or Paris. Multiplied in character as it has, the critical questions to ask, however, are: 'What makes a university a university and what, moreover, makes it a good university?' These questions are particularly important in the South African context where the different legacies the university has inherited pull it in a range of contradictory directions.

I make the argument in this chapter that as a modern social institution the university is distinct in that it is not set up for the purposes of social, cultural and economic reproduction. It is, of course, often a vehicle for the transmission of particular forms of power. But in the way in which it is constituted, in the ways in which the disciplines are structured to interrogate meaning, it has within it the potential for disrupting social, cultural and economic orthodoxy. This capacity is underpinned by its constituent elements. It is the one institution that rehearses the practices and modalities for the deconstruction of knowledges that authorise the disciplines - but also the methodologies for the reconstruction of self and community. 
To illustrate this argument this chapter shows how inescapably the challenge of the modern university is about the management of the contradictions that surround its constitutive character. These contradictions are fundamentally about defending and cultivating the status it holds in society while, simultaneously, fulfilling its obligation to be open and accessible. How it cultivates its distinctiveness from the structures of domination in the society in which it finds itself is a basic tension with which it is constantly confronted. In being a place which deliberately selects its members it has to ensure that its selectiveness does not default to and come to reproduce the social elite in whichever place it finds itself.

In the South African context this tension takes a particular form. At its heart is how it produces a self-conscious intellectual elite that is, firstly, acutely aware of the hierarchies of nation, people, community, race, class, gender, language, region and religion that surround it and give it its character, and that, secondly, is prepared through its commitment to intellectual freedom to struggle against those hierarchies. And so a question that is asked in this chapter is how is the university able to resist attempts to appropriate it for the reproduction of domination? How, when the very history and sociology of those who teach and learn within it are implicated in the making of political and economic hegemony, do these 'citizens' of the university refuse to avail themselves for that purpose or, minimally, come into the challenge of that space fully aware of the role they can play?

The challenge is intense and involves a re-imagination of the university, and particularly what it believes to be its mission, its 'natural' ambience, the intellectual ether on which it subsists. How it does this in the South African context, I argue, is by deliberately seeking out and imagining identity possibilities - languages and frameworks of self-description beyond the vocabularies of race and hegemony - that are not yet known, that are yet to be described and that await construction.

\section{The formative elements of the modern university}

To understand the power of the idea of the university it is important to describe the developments that took place around it in the late 1800s. A key moment leading up to these developments was the establishment of the University of Berlin by Wilhelm Von Humboldt in 1810. Humboldt's idea was that the university should have both a teaching and a research focus. Up until then the old universities of the world such as Oxford, Cambridge and Paris essentially prepared men for the priesthood. Their focus was the trivium grammar, logic and rhetoric - and the quadrivium - arithmetic, geometry, 
astronomy, music and science, and at higher levels, law, medicine and theology. Important as this curriculum was, it was approached in an entirely reproductive way. Debate was limited. The university was essentially a place of socialisation into the dominant conceits of the day. It was with the University of Berlin, and the Johns Hopkins University in Baltimore in 1867, that the idea evolved that the university could be a site for the production of knowledge.

Critically, Cardinal John Newman was making his great argument about the university at about the same time. Reflecting on what the university should be, he argued presciently that it is a 'place of concourse, whither students come from every quarter for every kind of knowledge' (Newman, 2001:1). He went on to say:

If I were asked to describe as briefly and popularly as I could, what a University was, I should draw my answer from its ancient designation of a Studium Generale, or 'school of universal learning'. This description implies the assemblage of strangers from all parts in one spot - from all parts; else, how will you find professors and students for every department of knowledge? And in one spot; else, how can there be any school at all? Accordingly, in its simple and rudimental form, it is a school of knowledge of every kind, consisting of teachers and learners from every quarter.

The global order into which Newman presented this idea of the university was quite extraordinary. It was a time of both productive and retrogressive social upheaval in the world. In the wake of the industrial revolution the emergence of influential thinkers such as Marx, Freud and Nietsche brought the ideas of the Enlightenment to a head. Behind many of their arguments was the large question of the nature of human subjectivity. Marx's Jewish Question, Nietsche's Ecce Homo and Freud's The Interpretation of Dreams had embedded in them a curiosity about the nature of being and the sociology and psychology of what makes human beings human.

It was also the period of colonialism and imperialism. The immensely important Congress of Berlin in 1878 saw the great powers sitting around a table and arrogating to themselves sovereignty rights over lands acquired by conquest, supposedly in the name of keeping the peace. On the back of an intense period of economic, military and naval expansion Great Britain assumed leadership of the globe. Accompanying these developments, and interpreting them, was a group of entrepreneurial scholars - archaeologists, natural scientists, historians and anthropologists - whose foundational works were to provide the basic explanations of the nature of the world; of native culture in Africa, India 
and elsewhere; and of European civilisation and the progress it represented. Often, though not always, projecting a curious mixture of brilliance and narrow-minded gendered and racial nationalism, they came to lay down some of the central approaches to explaining the ontological (the nature of being) and epistemological (ways of knowing) questions of the modern world.

It was in this contradictory space that the university had to work out its identity in terms of who it admitted and what it researched and taught. New disciplines like anthropology and sociology developed whose primary objective was the explanation of human difference. In the wake of neo-Darwinist understandings of evolution, especially early genetics and ideas of the survival of the fittest in particular, they came to account for human life essentially through a biological lens. There was at the same time a profoundly contradictory development: the existentialist framing of Dasein, the nature of being in the work of Heidegger who, as he was attempting to unfold the deep question of being, committed himself to the racist project of Nazism.

These simultaneous developments highlight the overwhelming contradiction that defines the modern university. As the preferred place for knowledge production - for the making of new knowledge - there is recognition that the university, as a site of education and learning, is different to other formative institutions. It is a place of excellence. On this ground it has to be vigilant about whom it admits into its ranks. It is, therefore, a place for an elite group of people. At the same time, however, drawing on discussions taking place in many parts of the world about the nature of what it means to be human, it is not a place one can search to find people deemed worthy of being a member of the university on the basis of pre-determined biological, cultural, linguistic, religious or gender attributes. The ability to excel, to emphasise the point, is not the preserve of particular groups of people. They do not, moreover, have in their traditions of thinking and deliberation sole access to higher order thinking. Capacity and intelligence are neither national nor racial in their essence, nor are they intrinsically linked to any gender, class or caste. Exclusive though the university is, it cannot base its membership on the dominant social categorisations and habits of thought which give the societies in which it finds itself their particular character.

In reviewing the history of the university, it is striking that hardly any country anywhere is able to produce this kind of institution. Important initiatives are taken in key parts of the world where intellectuals bring into being universities that are both excellent and open. Among these is Antioch University, established by the philosopher Thomas Mann in the United States. The single 
moment where a systemic solution was forced was in China during the Cultural Revolution of 1966-1976. The country's Communist regime had made the democratisation of higher education one of its principle tasks - to 'dismantle the elitism that had survived in the Chinese university system' (Beteille, 2010: 52). The idea was essentially to level the social landscape. The regime's motives, however, were entirely political. The system was effectively turned into a vast ideological factory.

Progress has been made around the world with the establishment of open universities, which have led to important breakthroughs in terms of access. Participation rates among young people have increased dramatically in countries such as the United States, where up to 70 per cent of young people find their way into higher education. But what makes a university a good university remains an intensely difficult question to answer. In the West, where the great modern universities are to be found, and increasingly in emerging economies such as China, India, Brazil and South Africa, the question of quality is dominated, and in some ways resolved, by two developments: the emergence of quality assurance agencies and a global preoccupation with university rankings. Both have their supporters and detractors.

Supporters of rankings base their defence of quality on the development of objective criteria such as the number of scholarly citations associated with an institution. That many of their conclusions are dependent on reputation in the market-place is, however, a weakness identified by many. Quality assurance agencies, on their side, develop a set of bench-marked instruments for assessing the presence or absence of minimum standards in institutions. Such standards emphasise efficiency and effectiveness. For the most part the university is projected and understood in terms of a broad, liberal, human capital approach. Politically progressive versions of this approach - and South Africa's model is globally significant in these terms - have a strong human rights orientation. In more general terms, however, quality assurance in these approaches is essentially a procedural question that pivots on what there is in the university, not on what that which is deemed to be important amounts to. There is little in what is promoted that actually explains what quality or excellence are.

It is against these developments and their ubiquity that I argue for the defence and even the development of Newman's idea of the university. Readings (1996:21) remarks about the easy way in which we have slipped into the language of 'world-class' and 'excellence' and urges that we deconstruct the terms we use and how we use them. His central thesis is that excellence is an 
empty signifier based on key performance indicators that themselves depend only on activity: 'all that the system requires is for activity to take place, and the empty notion of excellence refers to nothing other than the optimal input/output ratio in matters of information' (1996:39). The university, he says, has now lost all content (ibid). It has become another bureaucratic corporation. What remains, he argues, is the need to pay attention to the 'preservation of the activity of thinking' (1996:192).

This thinking, Readings argues, is an ethical responsibility. If the university is to preserve anything it is the necessity of ensuring that 'thought takes place beside thought, where thinking is a shared process without identity or unity' (ibid) (my emphasis). Wortham (1999:9), writing in the wake of Readings' provocation, takes the discussion further. To Readings' 'ruins' he proffers the idea of the university as an institution that has never historically been in symmetry: 'I shall argue, however, that disorientation (his emphasis) is the condition, the starting point, of a leverage by which such orientation is sought.' In Readings' account the new university stands at a moment of intense disorientation. The process of globalisation has dislodged it from its traditional anchor - the state. For Wortham, projecting the state as the anchor of the university is an overstatement which underplays the persistent disorientation on which the university has historically depended - its 'deep structure' (1999:10).

Bowden and Marton (1998:280) argue that a way to engage with this question of its structure is for the university to come to know itself. It has to be constituted as a place which understands the acts and processes of the different kinds of knowledge formation within the various domains of knowledge (1998: 287). How it operates as a site of knowledge formation enables the university to become 'aware of [how] one's (own) way of seeing opens up other options ... Taking other perspectives than one's own is vital in the university's dealings with the community' (ibid:293). This awareness, I suggest, is crucial. But how do South African universities stand in relation to this issue?

\section{What the South African higher education landscape looks like}

The American sociologist Michael Burawoy recently described the South

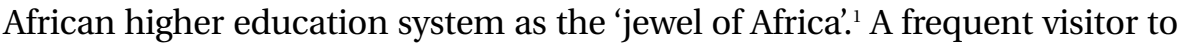
the country, he expressed a sense of amazement at the vitality of the system, remarking that the sector's preoccupation with questions of equality and the future of humanity made it distinctive in global terms. 
It is important to note what Burawoy is saying. There is an intensity in the South African discussion which is not as evident in many systems elsewhere. The South African discussion engages questions that arise in other universities but takes its intensity from its deeply conflicted history. How can it fulfil its promise and at the same time be a place which is inclusive? Can it be outstanding in terms of the new knowledge it produces and also be inclusive?

When thinking about inclusivity, South Africa is obliged to focus on access. Access is important because South African history contains the reprehensible reality, morally, politically and economically, that in terms of talent and how the education system has come to understand talent, it can actually only take to graduation 5 per cent of the cohort of black children entering school in any one year. This stands in contrast to the situation for white children. More than 60 per cent of young white men and women who enter the university are able to graduate each year.

Such statistics contain the nuances and shades of structural discrimination and the economic and social conditions that have made South Africa the difficult society it is. How, in a social and economic climate that has systematically failed to prepare particular groups of young people for university, does it include representatives of these groups in ways that promote the objective of excellence? What does this mean for the nature of the contemporary South African university? Must it re-calibrate its mission towards inclusion and wait for this inclusion to produce its own excellence in time? Should it force all its institutions to move in one direction? Should it differentiate itself in such a way that some universities will maintain their standards while others reconfigure their missions around their teaching obligations? How does one prevent differentiation becoming a mechanism for the entrenchment of race and racialisation?

How are South African universities managing this discussion? I suggest that the discussion is mired in its small and limited areas of interest and has become somewhat occluded. This occlusion is evident in the internal organisation of the system, its languages of self-description and its capacity for reimagining itself. I suggest that the institutions work with the legacy of apartheid in ambiguous ways. They are both repelled and seduced by it. They seek to divest themselves of it but are struggling to develop intellectual frameworks that will take them beyond it. What post-apartheid has made possible is the unmooring of institutions from their racial pasts. There remains, however, an inability within institutions and their academic disciplines to create the conditions by which the higher education system as a whole will begin the process of re-imagining both access and quality. 
Reviewing the organised work around change and reform that exists in the country, a conclusion to which one is forced to come is that the academy has side-stepped the issues placed in front of them and looked in the other direction. Aside from a proportion of vice chancellors at a number of universities who have explicitly committed their tenure of leadership to the issues of transformation, aside from a small and articulate group of young scholars who have organised themselves into a grouping called the Anti-Racist Network, and aside from individual groups of intellectuals who have inserted provocative new questions into their disciplines and academic practices, in its teaching, writing and professional organisation in societies the academy has been less responsive to the question of race and racism. It has chosen not to prioritise the explanation and description of the nature of the racial challenge, or, indeed, the ways that it forecloses the discussion of excellence and quality, nor has it afforded the undoing of that challenge its due importance. In relation to inclusion and exclusion its gestures have been deferential, submissive and at virtually every turn, unreflective. At the very moment when the formal procedures of epistemology have become available for the purpose of deconstructing reality, it has, one might argue, submitted instead to its wiles and seductions.

This submission is evident in the practice of disciplines and fields such as sociology, history, anthropology and education, where a form of complicity is evident in the very reproduction of the reality these disciplines were intended to uncover. The central accusation one can make of these disciplines' disciples is that they fail to see how the very social constructs they invoke in their teaching continue to circulate in their practices. Of these, the single worst example must be the Ubuntu class at the University of Pretoria that Jonathan Jansen (2009) refers to in Knowledge in the Blood. In such examples versions or interpretations of what is out there are presented as the truth.

Less offensive but no less egregious is the debate in much current sociology concerning the nature of South Africa's social reality. Strikingly, the discussion either accepts categories such as race at their face value or seeks simply to efface race from the situation. Many who operate from the latter position often seek to reduce the status of race to an epiphenomenon of class. Neither is able to engage with the complexity of racial ideology which characterised the landmark work of the 1980s when Wolpe (1988) and Alexander (No Sizwe, 1979) sought to generate theory that would explain the nature of modern South Africa. 
Why this situation has arisen is, I suggest, because the university has struggled to make an argument for itself. Instead, it has succumbed to limited explanations of what its purpose is. Two such explanations have contended for the high ground in South Africa and while discursive hybrids of them undoubtedly exist, the two represent the boundaries that demarcate the landscape. I have described these two explanations elsewhere as the outside-in and the inside-out views. Both are fundamentally about the social formation of the academic, about the making of the academic's identity.

The first view - the outside-looking-in view - sees the nature of the South African university, and particularly its racialised and racist practices, in terms of the university being merely another site of social practice in the country. The university is a social mirror of the broader society, made in its image. It is no more or less than any other site of public activity. In its everyday practices it provides a way of understanding the South African society. In this view the subjects of the university are sui generis - South African subjects. They have, therefore, all the attributes of the everyday subject. Racialised as those subjects are, the university therefore amounts to a racialised space.

The second view - the inside-looking-out view - presents the university as a space that is ontologically defined outside of and independent from the wider society. The university takes its rules and modalities of formation not from the society in which it is located but from the shaping and habit-forming discourses of the disciplines which constitute it. Subject formation in the university thus sets its citizens apart from the citizens of the everyday. The university subject, particularly its high priests and professors, are therefore a community apart, inured from the dross, the contumely, the prejudice, the venality, the myopia of the everyday world. Their internal rules of formation have protected them from the world of race and racism. They are above it.

Predictably, the first view seeks, as it does for the wider society, the deracialisation of the society. In this view the university is a project which is in need of reform or revolution. The second view denies that it is in need of any kind of reform. It is the outside world that is broken. It understands its own project best and any form of outside interference is a threat to its sacred rules of formation. Furthermore, it is the role of the university to take its holy knowledge to the outside. It is the obligation of the university to reshape the broken nature of the outside world.

Neither of these views, I suggest, is able to recognise the multiple social contingencies that enter our processes of making meaning, including our own investments in these positions. Neither is able to grasp the distinct and 
specific position which the university occupies in the modern era, much less the role of the university in the turbulent space of a world which is subject to rapid and constant change. The first urges the university to take its mandate from society. It presents the university as being out of step with developments in society. Mandated by the change that has taken place outside it, the university must now reform like the society itself. The second view asserts that the university has a non-negotiable autonomy from society. Society, constituted on the authority of everyday knowledge, cannot begin to comprehend the nature of the specialist knowledges which exist within the university and therefore cannot have any jurisdiction over it. The university must manage itself according to its own internal rules and regulations.

\section{Towards a new space}

To move to a more self-conscious theoretical position, one which is aware of how we take a position within the structures and narratives of our own social analyses, we need to develop a social criticism that is alert to the shifting relationship between cultural difference, social authority and political discrimination and that can deal with the dominant rationalisations of self and other. Such an approach would need to be aware of how much the ways in which we speak, our theories and languages of description are mobilisable for the dominant project of race and class. It has the potential to open up forms of seeing that take us beyond the stereotypical ways in which difference is understood. Critically, it unmasks the arbitrary ways in which the mark of the stereotype is assigned to each of us, particularly the racial, class, cultural and gender values that are supposed to define who we are. It has the potential to help us work in new productive spaces where we are able to confront processes of social and individual meaning-making - culture - in our lives and can recognise how those processes, in their innovativeness, continually produce new forms of oppression and emancipation. It can also permit us to see how - and this is an important point - each of us is implicated in these processes. From such a position we can develop a project of emancipation that is fundamentally conscious of the complex ways in which we are positioned and position ourselves. We can begin to see each other in our heterogeneity and deal with, and not disavow, the proclivity within us to 'other' as we socially identify. The power of such an approach is to force us to realise the limitations of consensual and collusive theories of community embodied in notions of race, class, gender, culture and so on.

What options are open for the system to deal with the issues of access and quality, openness and excellence? 


\section{Where are the opportunities?}

A number of initiatives that have materialised seek to engage the twin questions of access and quality. I have elsewhere described the range of developments that have emerged in the universities around the identity question (Soudien, 2011). Whilst these are important, they do not look at the issues of access and excellence together. I draw attention to the following initiatives aware that others may exist. Two that are key include:

The admissions debate at the University of Cape Town (UCT) ${ }^{2}$ which is fundamentally concerned with managing the twin demands of excellence and redress

- The discussion on some campuses such as the University of Fort Hare $(\mathrm{UFH})^{3}$ for the need of a compulsory foundation programme for all students which will raise their levels of social awareness around social justice issues.

In each situation there is some possibility, though both are encumbered by unresolved issues. I address some of these briefly.

The admissions debate at UCT has been extensively covered in the popular media. The debate was the result of the University's decision to develop an admissions policy that dealt fairly with apparently contradictory requirements of excellence and social redress. The purpose of the policy was to continue placing a premium on excellence while, simultaneously, acknowledging the persistent effects of inequality on the performance at the school-leaving point of disadvantaged students. In including affirmative action based on race in this policy, and thereby operating a policy which set the admissions' points benchmark at a lower level for black students than for white students, the University was criticised by some for returning to what was described as an apartheid approach. It raises, however, a question which India has been grappling with for the last thirty years - that of affirmative action. In India the question has been forcefully put by some commentators in a way that possibly sounds reactionary: is it the university's business to be admitting students, irrespective of their social status in the wider society, who have no prospect of succeeding within it, or of taking onto the professoriate individuals who do not bring to the job of a professor the appropriate kinds of qualities? The argument being made is that affirmative action (Beteille, 2010) has almost irrevocably damaged many institutions. In India and South Africa key scholars are arguing that the kind of affirmative action used in the two spaces - quotas in the main - only serve to reproduce caste and racial stigma, and neither caste nor racial affirmative action understand the sociological 
processes for bringing these forms of hierarchy to an end. What is needed, so the argument goes, is the fundamental improvement of the school system to ensure that anybody from within the society can enter the university on a non-contingent basis. The point remains, however, that within the discussion lie important opportunities for thinking about rights and redress and, at the same time, for excellence.

The grounding programme at the UFH is an important initiative which aims to provide all of its students with the intellectual tools to interrogate questions of equality and citizenship. The programme is based on intensive introductions to both the country and the world's major social issues and the frameworks that are used to make sense of them. In terms of access and excellence it is a significant initiative. While the UFH, unlike the more select institutions in the country, has not needed complex admissions policies and procedures, and in these terms has not had to problematise access, it is by definition a relatively open access institution. It is in terms of excellence that the grounding programme presents the country with an important model of how, in its form, the questions of excellence and access can be resolved. ${ }^{4}$ The programme begins with the recognition that students do not have all the reading skills to manage a university programme and then deliberately constructs a reading, writing and presentation preparation course over a year which appears to bring them to high levels of cognitive engagement with major social issues.

To assess these initiatives in terms of how they suggest a way forward for the universities to be both open and excellent would require a great deal more time. Nonetheless it is crucial that the country is engaging with the questions. This engagement is yielding important insights and bringing to a point of clarity difficult sociological puzzles. One such puzzle, for example, arises from the insights being generated at the University of Cape Town in its debate around social class and race in admissions. The two are so tightly bound that one needs to be constantly pushing the analysis of the social subjects to understand clearly what a class, as opposed to a 'race', effect is and to avoid the ideological confusion that follows when they are conflated.

The gains, however, are essentially in the nature of clarification of the issues and a clearing-of-the-ground. More needs to be done to bring institutions to the point where they understand themselves more consciously and can see how they are implicated in the reproduction of privilege. Until this is done and is specifically articulated in policy and followed through in practice, the university will continue to be trapped within the logic of either the patriotic or the republic-of-letters discourse. The discourse it needs is a brand new one that re-imagines the university on terms that are self-critical and courageous. 
THE PROMISE OF THE UNIVERSITY: WHAT IT'S BECOME AND WHERE IT COULD GO

\section{Notes}

1 Comments made at the Department of Higher Education and Training Summit on transformation, Cape Town, 7 April 2010.

2 UCT is a traditionally white institution.

3 UFH is a historically black institution.

4 I had the benefit of conducting interviews with key students and staff in the programme in September 2010 and am basing my assessment of the programme on that visit.

\section{References}

Beteille, A (2010) Universities at the Crossroads. New Delhi: Oxford

Bowden, J and Marton, F (1998) The University of Learning. London: Kogan Page

Department of Education (2008) The Report of the Ministerial Committee into Transformation in Higher Education. Pretoria; Department of Education

Jansen, J (2009) Knowledge in the Blood: confronting race and the apartheid past. Stanford, CA: Stanford University Press

Newman, J (2001) The idea of the university. http://www.newmanreader.org/works/idea/. (accessed May 2012)

No Sizwe, Neville Alexander (1979) One Azania, One Nation. London: Zed Press

Readings, B (1996) The University in Ruins. Cambridge, Mass: Harvard University Press

Soudien, C (2011) The Arhythmic Pulse of Transformation in South African Higher Education. Alternations 18 (2) 15-34

Wolpe, H (1988) Race, Class and the Apartheid State. London: James Currey

Wortham, S (1999) Rethinking the University: leverage and deconstruction. Manchester: Manchester University Press 